\title{
MODEL COLD CHAIN MANAGEMENT OF BEEF IN INDONESIA: A BUSINESS PROCESS
}

\author{
Resista Vikaliana \\ Institut Ilmu Sosial dan Manajemen STIAMI \\ Department of Logistics \\ Email : resista@stiami.ac.id
}

ARTICLE INFO

Keywords :

management, cold chain, beef, Indonesia

\section{ABSTRACT}

This paper aims to study the results of research related to cold chain management of beef in Indonesia. The methodology used is literature study with descriptive research type analysis. In this study recommended cold chain and cold storage are one of the most important elements to help improve the quality of meat distribution throughout Indonesia. To create an effective and competitive cold chain, the role of all stakeholders is required. Beef Cold Chain Management in Indonesia is expected to effectively meet the needs of protein, especially beef throughout Indonesia at affordable prices society.

\section{INTRODUCTION}

Animal products are one of the protein rich sources of food needed to build a healthy and intelligent society. However, food products of animal origin constitute one product that is categorized as perishable food and potentially bring danger to the consumer's health (potentially hazardous). The need for beef to meet protein needs in Indonesia is quite high. In comparison, Malaysia is the country with the highest per capita consumption of meat per year, followed by China, Indonesia, then Thailand and India. Based on data from the Central Bureau of Statistics (BPS), domestic beef production in 2018 reached 403,668 tons. However, domestic demand for beef demand in 2018 amounted to 663,290 tons.

Table 1 Beef Production 2013 - 2017 (in Tons)

\begin{tabular}{|l|l|l|l|l|}
\hline 2013 & 2014 & 2015 & 2016 & $2017^{*}$ \\
\hline 504.818 & 497.670 & 506.661 & 518.484 & 531757 \\
\hline
\end{tabular}

*preliminary figure

Source : Livestock and Animal Health Statistics, Directorate General of Animal Husbandry and Animal Health, Ministry of Agriculture, 2017 
Meanwhile, livestock logistics problems in Indonesia are still experiencing some obstacles. The geographical form of Indonesia, which is an archipelagic country, implies the necessity of the most optimal mode of transportation to transport live cattle to cut meat, packaging of product livestock products considering regulation, cost efficiency, transport infrastructure, wholesale and retail capacity, quality and weight of goods, consumer preferences and environment (waste management). According to EIBN Report (2016), as an archipelago, Indonesia needs the right supply chain to ensure the distribution of goods to all regions. Slow infrastructure development hampers the distribution of goods quickly, especially fresh produce that need special attention. The distribution of goods in Indonesia is unbalanced, with most products available concentrated in Java, where more than 50\% of the total Indonesian population lives. There is difficulty in accessing and delivering fresh products to all islands in Indonesia. This results in, products sold outside Java having limited inventories and at a higher price. The need for animal product consumption is increasing along with the increase of population growth and public income, so it becomes the responsibility of government and business actors to be able to guarantee the availability of supply and distribution of products nationwide. Directorate General of Livestock and Animal Health in 2014 conducted a study by disseminating surveys to the community. In general, people in Jakarta Capital City argue that frozen products have a quality that is not as good as fresh products. Both regulations govern the implementation of cold chain as the post-harvest handling of beef and chicken meat which includes the use of cold storage. Frozen meat storage is expected to be a buffer stock to balance the supply of meat demand.

The Indonesian government has taken note of the situation and is gearing up to work on cold storage projects. The Logistics Agency is studying the possibility of building national cold storage services, while the Ministry of Marine Affairs and Fisheries is focusing on developing smaller sized storage and ice flake factories across the region. Moreover, the regulation related to cold storage investment is heading towards significant improvement, highlighted by the Government's decision to open the cold storage sector $100 \%$ to foreign investment. Indonesia occupies a high-potential position as a potentially huge market for infrastructure investment. Many challenges, however, limit the interests of cold chain providers. It is the fourth most populous country, and its booming economy is experiencing rapid revenue increases.

Based on the above issues, this paper aims to conduct a study by studying the results of research related to supply chain management of cold beef in Indonesia.

Based on Indrajit and Djokopranoto( 2002), supply chain is a concept where there are regulatory systems related to product flow, information flow as well as financial flows. This arrangement is 
important to do with the number of links involved in the beef supply chain and the price is relatively high when compared with other livestock commodities. Activities in the supply chain is a process of delivering products originally in the form of live beef cattle into beef ready to be marketed from beef cattle ranchers to meat consumers. Mistakes in choosing distribution channels can slow down and even congestion of goods and services delivery from producer to consumer. The length of supply chains in livestock products if not properly managed can lead to high costs, both for transaction costs, transportation costs, storage costs, packaging costs, damage costs and benefits of each actor and so forth (Mulyadi, 2005). According to Emhar et al. (2014), the regulation of product, financial, and information flow in a supply chain is important in livestock and beef commodities due to the large number of business actors involved, the characteristic of perishable beef products, and the prices often fluctuate and a certain period of high price increases.

According to Indonesia Cold Chain Association, cold chain is a network or refrigerator, cold stores, freezers and cold boxes organized and maintained so that foods are kept at the right temperature to remain potent during foods transportation, storage and distribution from factory to the point of use. . Here is a picture of cold chain for value preservation

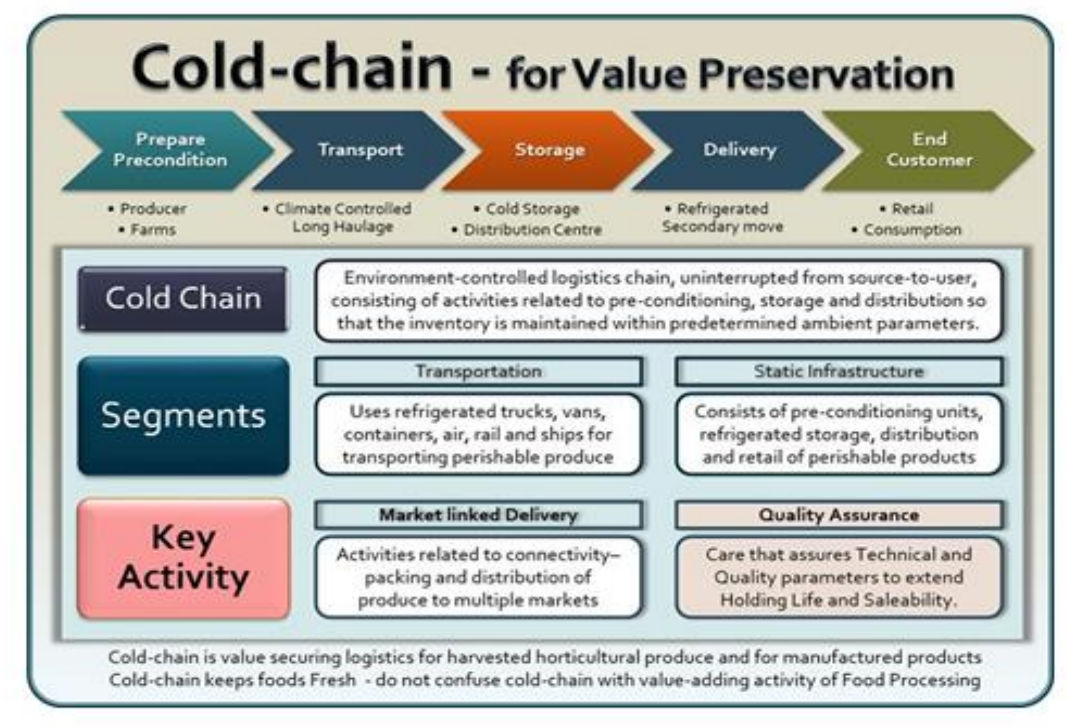

Figure 1 Cold Chain for Value Preservation 
Cold Chain System consists of Production Zone and Consumption Zone. The system described in the following figure

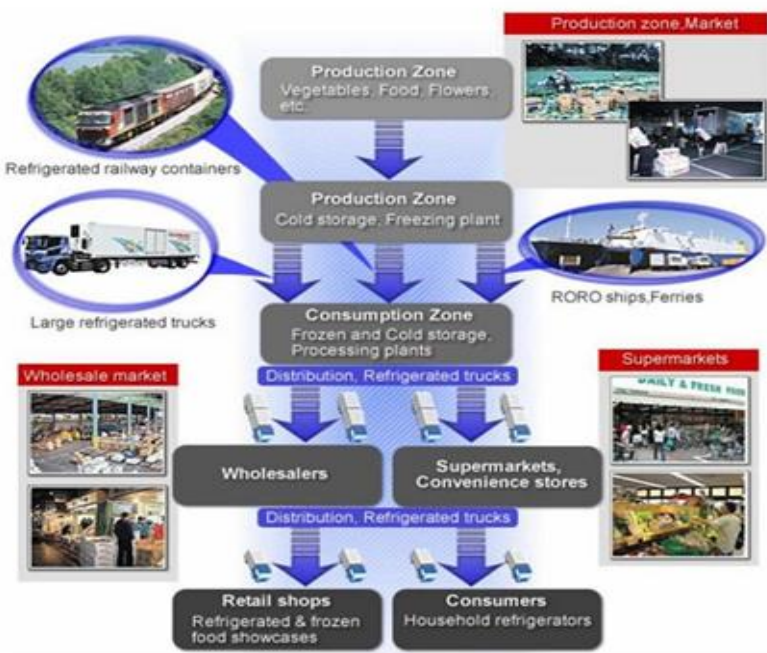

:CFCFA Logistics Management Training : Cold Chain Logistics 6

Figure 2 Cold Chain System

The following is a cold chain relationship when associated with the infrastructure

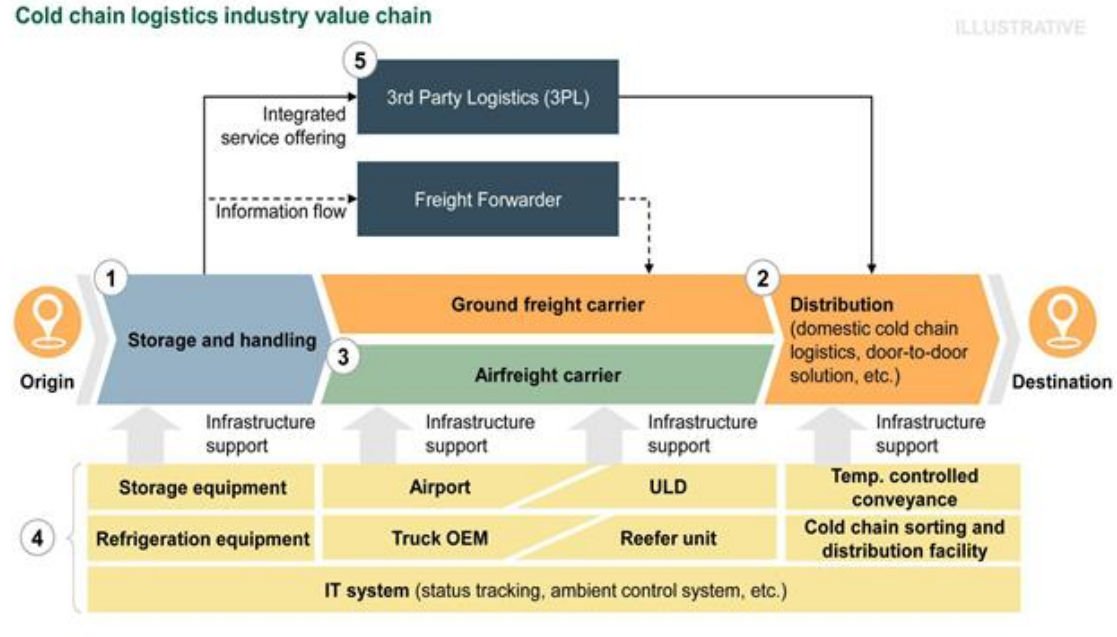

Soucer LEK andins

Figure 3 Cold Chain Logistics

From the picture above, Freight forwarder and 3PL are stakeholders involved. From origin to arriving at the destination, the required infrastructure is storage equipment, refrigeration equipment, airports, OM trucks, to cold chain distribution facilities. Everything is integrated with the control system through the IT system. 


\section{METHOD}

The methodology used in this paper is literature study with the type of descriptive research analysis. Journals and related institutional reports are used to analyze the management of the meat supply chain in Indonesia.

\section{RESULT AND DISCUSSION}

\subsection{Result}

Saptana et all (2017) The supply chain channel is very diverse and quite long with the main role of collector traders between villages / sub-districts and cutter / butcher traders, and inter-regional traders / distributors. The performance of supply chain management of livestock commodities shows that the type of supply chain management structure of cattle and beef cattle is classified as "market linkage" with low to moderate level of performance. The policy implications for improving the performance of supply chain management can be done through horizontally integrated efforts, improving the performance of supply chain management by involving small and medium / large scale enterprises, and increasing vertical integration partially towards a more holistic direction. The picture below describes the supply chain of beef in Indonesia.

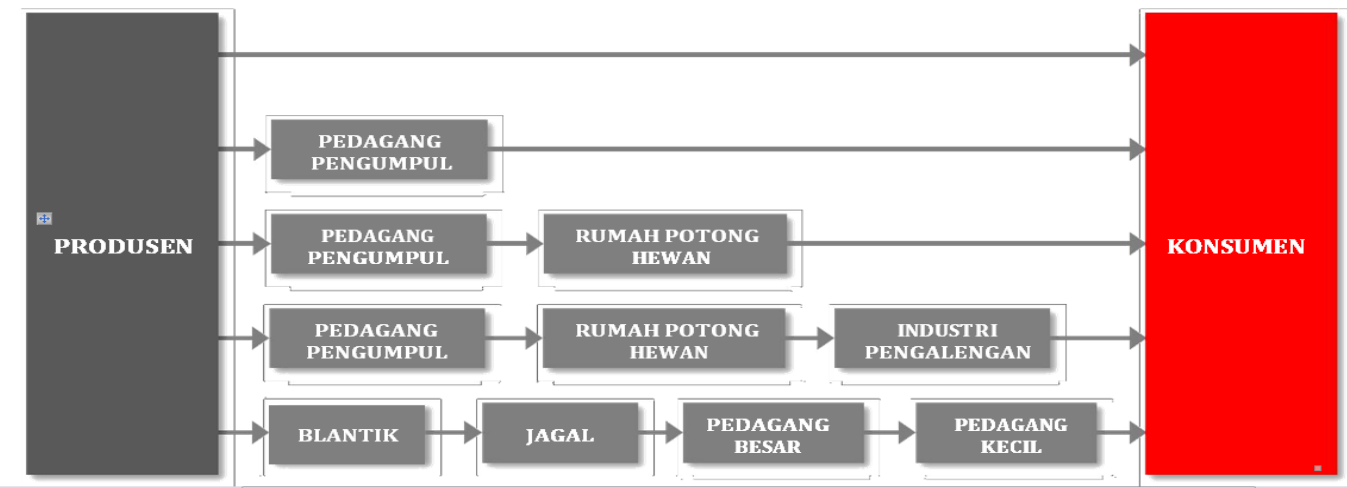

Figure 4 Beef Supply Chain in Indonesia

In general, the beef supply chain is illustrated below (Supply Chain Indonesia Report, 2015).

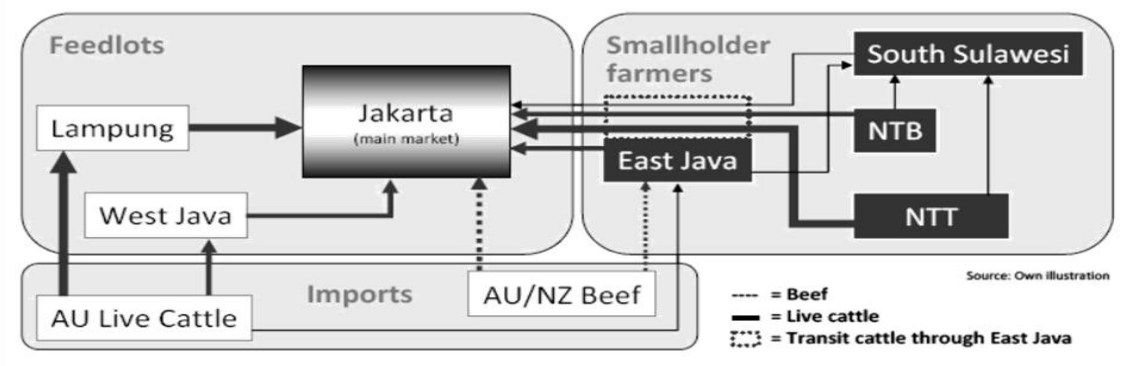

Figure 5 Beef Supply Chain in Indonesia (in general) 
According to Supply Chain Indonesia report in 2017, at the level of Animal Slaughterhouse, the application of cold chain is recommended to overcome the impact of halal risk and meat quality While at the retailer level, the application of cold chain is recommended to overcome the problem of meat safety risk and meat quality. The following is temperature range of beef.

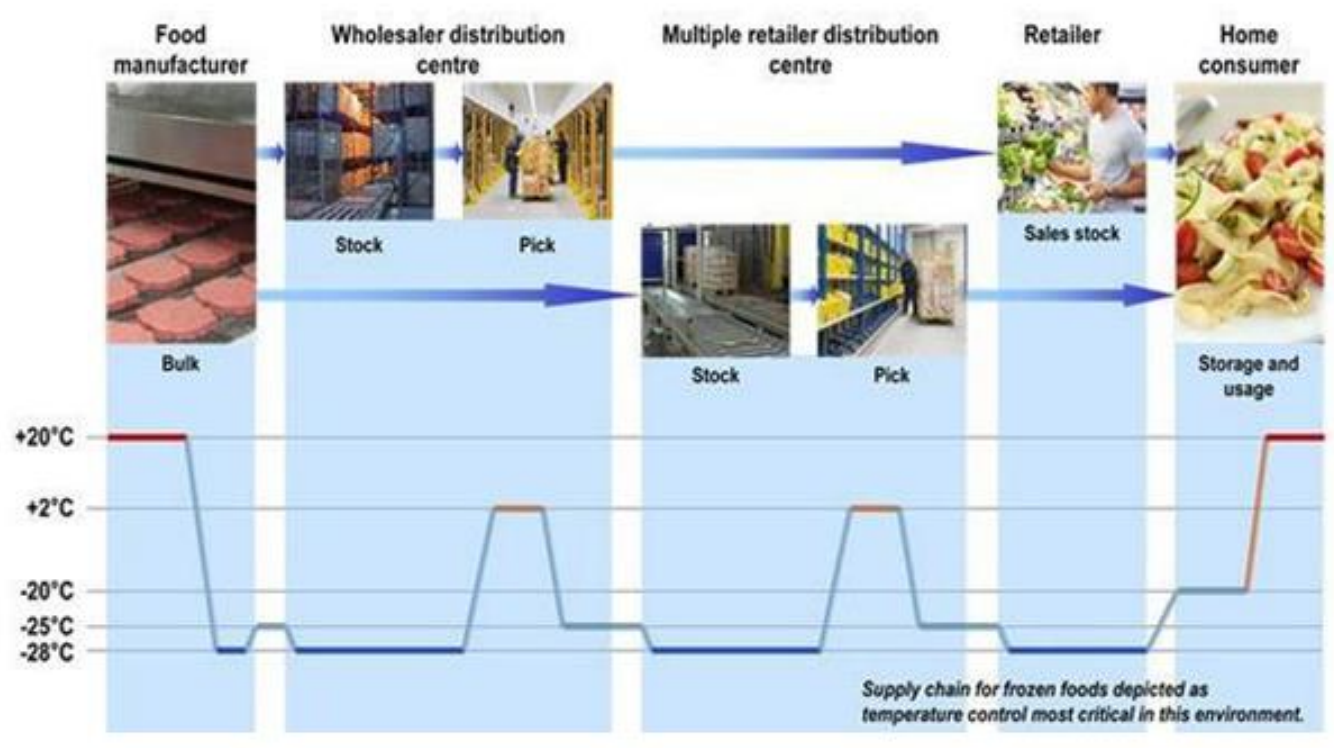

Figure 6 Temperature Range of Beef

Cold storage and cold chains have always been part of Indonesia's logistics and supply chain. The cold storage available in Indonesia can be divided into four categories; chilled rooms, freezer rooms, blast freezers, and blast chillers. Each of the storage options are designed with certain temperature settings depending on their purpose and cold storage facilities in Indonesia are of both commercial and industrial types. Indonesia has also applied integrated and non-integrated business models, depending on the company's business purpose and available investment.

The demand for cold storage and cold chains comes from many sectors, such as the food and beverage sector, pharmaceuticals and the retail sector. The food sector is always closely linked to cold storage and cold chains, in particular, the fisheries sector. Despite its growing production, there are not enough cold storage or cold chains available for fisheries, beef, and poultry distribution. According to Yasni (2017) lack of cold chain implementation in Indonesia are :

1. Shipping live cattle using open trucks, both by land and sea.

2. Supply chain has long links: breeder, beautician, animal market, collecting merchant, butcher, $\mathrm{RPH}$, new to consumer. 
3. Facilities that are still lacking, such as: Slaughterhouse national standard, industry information and tariffs, and lack of knowledge about cold chain.

4. Temperature fluctuations are not good during distribution.

5. Means of temperature control and data logger

6. Unloading loading procedures are diverse and undisciplined.

7. Distribution of production areas are fragmented and not in full support by RPH berstandard and cold chain system infrastructure is good.

Cold storage demand is closely related to other food production such as beef and poultry. The Indonesian government targeted beef production at 580 thousand tons in 2015, whilst at the same time reducing beef cattle imports. Moreover, in poultry production, the government expects growth to be between 7-10\% every year. (EIBN Report, 2016).

In 2016, the installed capacity of refrigerated logistics can only support $25 \%$ of local meat production and $80 \%$ is used as a cold chain of imported meat, or equivalent to only $44 \%$ of national needs per year (2016).

\section{Discussion}

If we compare with cold supply chain management in Japan, cold chain management involves the private sector with public private partnership (Kato, 2013)

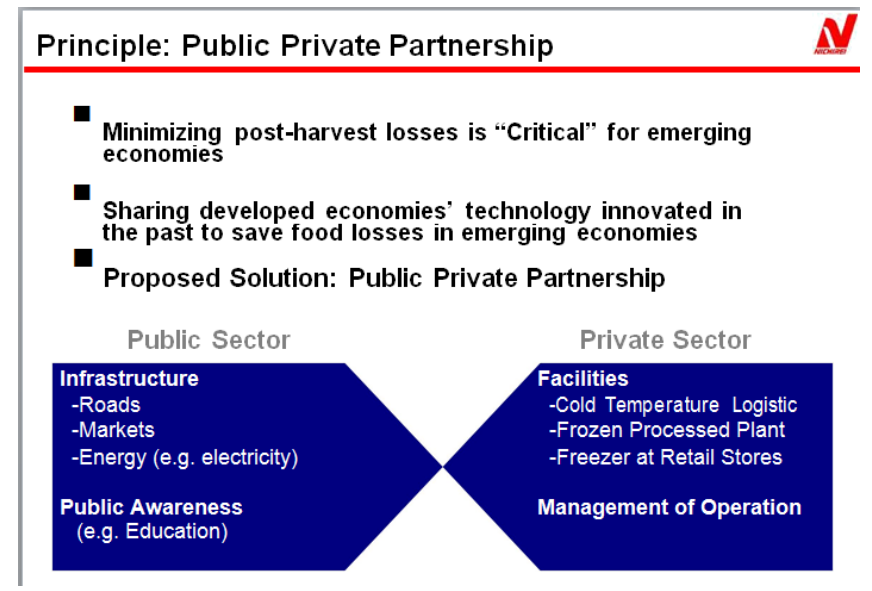

Figure 7 Public Private Partnership of Cold Chain in Japan

\subsection{Beef Cold Chain}

Cold chains are becoming more important in the Indonesian transportation business, as Indonesian consumers are demanding better quality and are becoming more interested in buying imported products. The producer needs to ensure the product's freshness and quality until it reaches their 
customers. Cold chains play an important role by transporting the food safely, while preserving the texture, taste, and nutritional value of the food. Modern cold chain carriers require well developed equipment and IT systems to support their operations, for example by installing a device to track, not only the location of the package, but also its temperature, and an accompanying IT system capable of analyzing the data. The system, Cold Chain Logistics Information System, is described in the following figure.

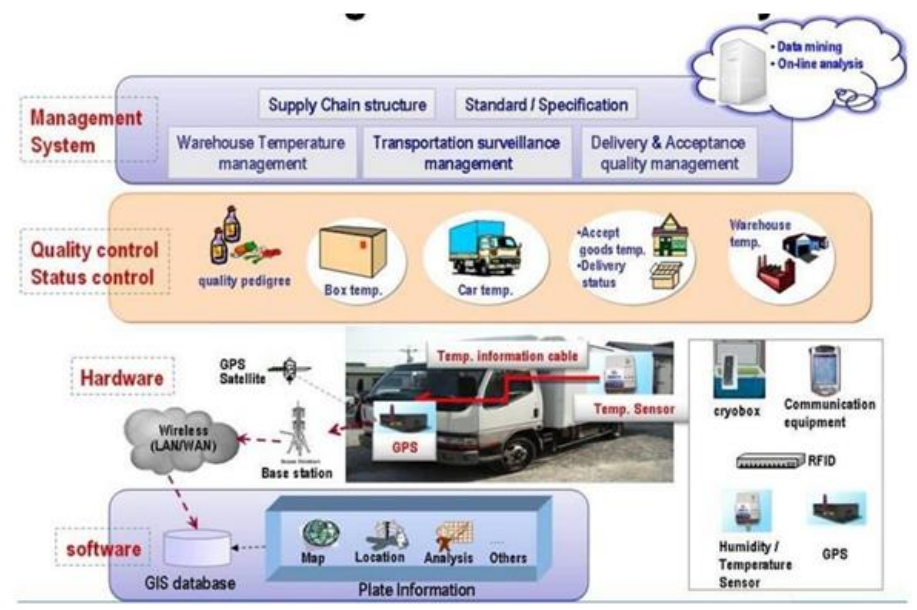

In Indonesia, logistic companies who professionally operate cold storage as part of their core business, also often provide cold chain transport services. The logistic company handles the transportation of the product from source to the storage facility, and sometimes even to the final retail destination. The company is also responsible for controlling and maintaining the product temperature during transport.

On the infrastructure side, the Ministry of Marine Affairs Fisheries aims to build 250 cold chains across the Indonesian archipelago by 2019 , with $60 \%$ of the cold chain to be built in the eastern part of the country where most of the fishing grounds are. A pilot project has been implemented in several places such as Muara Baru, Muara Angke, Bitung, Belawan, and Surabaya. Furthermore the ministry wants to build ice flake factories in 333 spots in order to supply the cold storage and cold chains with proper refrigerant. Currently fishermen use ice blocks that take up a lot of space and are less hygienic. Ice flakes will provide better temperatures, take up less space, are more hygienic, and have better endurance.

\section{CONCLUSION}

Cold chain and cold storage are one of the most important elements to help improve the quality of meat distribution throughout Indonesia. To create an effective and competitive cold chain, the role of all stakeholders is required. Beef Cold Chain Management in Indonesia is expected to effectively meet the needs of protein, especially beef throughout Indonesia at affordable prices society. 


\section{Referensi}

(Damopolii, 2018)

[1] Indrajit, R.E. dan R. Djokopranoto. 2002. Konsep Manajemen Supply Chain. Cara Memandang Mata Rantai Penyediaan Barang. PT. Gramedis Widiasarana Indonesia. Jakarta.

[2] Kato, Naoji. 2013. Cold Chain Infrastructure and related Industries-Contribution to food losses / waste reduction-Symposium on Human Resource Development in Food-related Area through Partnership with ASEAN Universities Jakarta, Indonesia, January 21, 2013

[3] Mulyadi. 2005. Akuntansi Biaya edisi ke-5. Cetakan ke-7. UUP STIM YKPN. Yogyakarta.

[4] Rodrigue, Dr. Jean-Paul and Dr. Theo Notteboom, The Cold Chain and its Logistics, The Geography of Transport Systems, Hofstra University, New York, 2016, available at : https://people.hofstra.edu/geotrans/eng/ ch5en /appl5en/ch5a5en.html

[5] Saptana and Nyak Ilham 2017. Supply Chain Management of Cattle and Beef Commodities. Jurnal Analisis Kebijakan Pertanian, Vol. 15 No. 1, Juni 2017: DOI: http://dx.doi.org/10.21082/akp.v15n1

[6] Yasni, Hasanuddin. 2017. Cold Chain System Untuk Industri Logistik Peternakan Asosiasi Rantai Pendingin Indonesia/ Indonesiaa Cold Chain Association

\section{Internet Source:}

[7] Manajemen Rantai Pasokan Sapi Potong di Indonesia. www.SupplyChainIndonesia.com. 2016

[8] Saatnya Terapkan Sistem Rantai Dingin (Cold Chain System) Untuk Daging Yang Berkualitas Tanggal Posting : 07 April $2018 \quad$ Publikasi : $\quad$ (admin) | Hits : 285 http://ditjenpkh.pertanian.go.id/saatnya-terapkan-sistem-rantai-dingin-cold-chain-system-untukdaging-yang-berkualitas diakses 24 Mei 2018

[9] Ministry of Agriculture Statistics and Information System, available at : http://www.pertanian.go.id/ASEM2015-NAK/Prod_DagingSapi_Prop_2015.pdf 